\title{
14 No Factory for Dreams: Street-Level Bureaucrats between Activation Targets and User Orientation
}

\subsection{Introduction}

Street-level bureaucrats, the people who produce and deliver public services through direct encounters with citizens, are vital democratic actors in (at least) two respects. Firstly, they are set to implement the policies that democratically elected bodies prescribe. As it is impossible to prescribe in detail how to handle each and every encounter with clients, patients, students or whatever capacity it is in which the frontline organizations approach the public, the professionals who work in these organizations are given discretionary powers to decide exactly how each case should be handled. In Bo Rothstein's words: 'It is the sum of their actions which constitutes the public program. As to whether these actions reflect the objectives laid down by the democratically constituted organs - this must be regarded as an open questions' (quoted by Molander, 2016, p. 16). Secondly and following this, they not only implement policies from above; they also face (often quite literally) citizens at the street-level. These are citizens with rights and entitlements, and it is the character and quality of these encounters which to a large extent determine the degree to which these rights and entitlements are being fulfilled. The quality of these experiences may again influence how people perceive the welfare state and their general political trust - in other words, their faith in the workings of democracy (Rothstein \& Kumlin, 2005).

In this chapter I will discuss these issues in light of the implementation of active social policies in street-level bureaucracies in Norway, drawing on data from empirical fieldwork in two local 'NAV-offices', local branches of the Norwegian Labour and Welfare Administration (NAV).

Underlying nearly all welfare policy reforms in Norway for the past few decades is the idea of arbeidslinja, in English literally the 'the work-line'. This has been defined as the principle that all welfare arrangements should be designed to encourage and facilitate labour market participation. In fact, we could consider the workline policy as a social institution that defines, governs and constrains action in the welfare state (Pierson, 2006). It is underpinned by normative justifications (work ethic, sustainability concerns, justice), by legal/organizational structures such as income security schemes (economic incentives, conditions, entry criteria) and by the work procedures in welfare bureaucracies (assessment of income claims, activation programmes).

Despite broad political and popular support for the work-line there is less satisfaction with respect to the welfare state's ability to put these principles into practice and produce the desired outcomes. One of the targets of criticism has been 
the frontline organization that delivers welfare policy in practice, namely the reformed NAV. NAV is the result of a major organizational reform (rolled out from 2006) whereby national labour market services, national social security services and municipal social assistance were merged and is thus responsible for the implementation of most aspects of Norwegian social policies.

NAV's street-level bureaucrats (SLBs) have come under attack both from above and from below. Expert reports have claimed that NAV staff do not possess the right competence, that they do not see their clients in the way that is required by policy and that they focus too much on their users' (often health-related) barriers to work instead of emphasizing their opportunities in the labour market (Bay, 2015; Ekspertgruppen, 2015, p. 10). In short, street-level bureaucracies do not deliver the outcomes democratic bodies want them to produce. In another type of critique, often communicated by the users of NAV through the media, another picture emerges. It is a story about a welfare bureaucracy that is rigid and rule-orientated, where the individual circumstances of people's hardships are ignored and where claimants are left without the necessary income support or are forced into demeaning activities despite difficult health conditions.

The purpose of this chapter is not to judge if or to what extent the SLBs of NAV fail in fulfilling their democratic mission. What I will do is, first, present and discuss the challenges of discretionary practice in the welfare state's frontline organization in a democratic perspective and, second, analyze how SLBs themselves relate to some of these tensions through their own reflections over the practical work they are engaged with.

\subsection{Democracy, Discretion and Street-Level Bureaucracy}

In an ideal type representation of democracy the people elect its governors, who are thus empowered to make policies, which are subsequently implemented by administrators or bureaucrats. Politicians make policies, while a neutral state apparatus implements the ideas in practice. If the implementing agencies fail to implement the policies as intended, we have a democratic problem.

From this perspective, discretion becomes inherently problematic. Discretion means that professionals or other occupational groups are entrusted to apply their professional knowledge to particular cases (Molander, 2016, p. 2). Discretion does not mean acting freely; discretionary powers entail power exercised under some form of rule (Goodin, 1986, p. 235). The tasks that street-level bureaucrats perform are regulated by law, but they cannot be specified in advance in a way that gives precise guidelines on how to handle each one of them. For the 'principal' (the public through its elected governors) to control the 'agents' (the SLBs), frontline organizations need to be organized in ways that ensure discretion is employed and policies are implemented in ways that are consistent with policy-makers' intentions. This can 
happen in different ways: through hierarchical control and the detailed regulation of work procedures (traditional bureaucratic structure), by establishing market-like structures such as incentives and targets that direct action in the desired direction (as in new public management reforms) or normatively by nurturing within officials certain ways of thinking about the work they are set to do (e.g. professional ethics) (Newman, 2007).

There are good reasons to problematize the distinction between policy and the implementation of the principal-agent model. In a way, this is what Michael Lipsky's seminal work Street-Level Bureaucracy. Dilemmas of the Individual in Public Services (1980) does. Until this work, the literature on implementation had tended to focus on deviance between policy and implementation. SLBs were portrayed as failed or inefficient agents of policy implementation (Brodkin, 2013). However, this view does little in terms of problematizing policy itself. Lipsky stressed that policy goals are ambiguous and often potentially contradictory. Welfare bureaucrats are to activate people and try to get them into work but also maintain their rights to income security - how to balance between the two? Other goals are too idealized (work for all); such goals may make sense as a moral compass but are difficult to achieve in practice and gives limited guidance for action. Work may not be achievable for everyone who is enrolled in activation programmes - how do you design a meaningful activation plan for them? Often conflicting interests and tensions are not resolved when policies are adopted at the political level, and it is left to the SLBs to make practical solutions in individual cases. Client-focused goals of individual treatment, close supervision and tailored assistance may in practice be displaced by organizational goals of effective management of large caseloads.

SLBs have to use discretion to do their jobs. Regulations and guidelines are either too general or too voluminous and internally contradictory to provide a blueprint for action in each client encounter. Policy may specify that NAV clients should be enrolled in active measures, but discretionary judgements must be made with respect to the content, timing and intensity of the activation. Some SLBs are professionals and are expected to adhere to professional norms and find guidance in their professional expertise when exercising their discretionary powers, but semiand non-professionals without access to a similarly codified knowledge base also need to make discretionary judgements. While policy-makers may wish to and try to limit discretion, the situations SLBs are set to manage are too complex, and often incorporate a strong human dimension, for discretion to be eliminated from the implementation of public policies.

In short, Lipsky concludes that SLBs are effectively making policies and thus play a highly political role in the welfare state. He does not problematize this in terms of democracy. What he does is show that even if public service delivery may be flawed, the problem needs to be understood in light of the specific structure of this kind of work - ambiguous goals, boundless demands and limited resources. 
Thus he refrains from placing the blame on the individual street-level worker in regard to his/her inadequacies, incompetencies or other individual shortcomings.

Lipsky wrote his book before the breakthrough of new public management (NPM) and the welfare state reforms that followed in its path. Many of the ideas and practices of NPM build precisely on the sorts of distinction between policy-making and implementation that Lipsky sought to break down: politicians should concentrate on establishing policy and setting goals and refrain from involvement in the dayto-day operationalization of political targets. The implementation of policy should be left to the relevant specialists and agencies. They are empowered to make their own independent decisions but must do so within an externally imposed framework of politically determined goals, performance targets and output controls. In other words, through the dichotomy between policy and operations, politicians are made responsible for policy and managers for operations.

Again the problem of drawing such distinctions in practice is left unproblematized. Is it policy or implementation which has failed when someone does not get their benefits? Whose responsibility are the alleged failures of the NAV-reform? The policymakers who came up with the idea? The top-level managers trusted to implement it? Or the SLBs who cannot meet targets, lack labour market competence or fail to maintain work orientation? The irony, says Paul du Gay (2000, p. 124), is 'that governments which have sought forcefully to depoliticize the activities of state bureaux by curtailing the policy responsibilities conceded to officials, have ended up by politicizing [...] the conduct of those very same officials in the process of making them only responsible for implementation'. He points to what he conceives as a democratic problem. Du Gay treasures the independence of bureaucracy, its role as a counterweight to politicians, which, he argues, in NPM reforms is reduced to obedient will-do-agents of policymakers. It is precisely because the policy-operations dichotomy is impossible to operationalize, he argues, that politicians have received a 'perfect vehicle for allowing ministers to absolve themselves of their responsibilities to Parliament by defining any problem as "operational matters"' (2000, p. 132). Political reforms, such as the NAV reform or activation policies, become organizational matters, and their perceived failures become the responsibility of NAV management (and, we may add, SLBs).

Distrust of bureaucracy indeed underlies much of the public sector reform of the past few decades. This applies not only to the top echelons of state bureaucracy that du Gay writes about but also to SLBs. Julian Le Grand interprets the reforms of the British welfare state in the 1980s and 90s in terms of shifts in 'policy-makers' beliefs about motivation - what motivates those working in the public sector - and agency - the capacity of individuals, especially the beneficiaries of welfare, to engage in independent or autonomous actions'(Le Grand, 2006, p. xii). In his terms, public streetlevel bureaucrats have gone from being viewed as altruistic knights (as bureaucrats appear in Du Gay's account) to be seen as self-interested knaves. Professionals used to be trusted to be motivated by their professional ethics and primarily concerned with the interests of the people they were set to serve. Bureaucrats were trusted to be ruled 
by their bureaucratic ethos. This belief faltered; public sector workers were seen as motivated by their own interests rather than the public good.

At the same time, new ideals about service users' competence and capacity to make autonomous choices emerged. Clients were not to be treated as passive recipients of goods and services, delivered by professionals who knew better than themselves what would be in their interest. On the contrary, they were capable of knowing their own interests, and their preferences were to take a more leading role in welfare delivery. They went from being considered pawns to become queens. In the context of NAV, citizens are no longer referred to as clients but as users. (On the other hand, they are not exactly queens either as their preferences have to bow to the goals of the work line.) In other contexts they have become customers. The NPM organizational solution was to restructure the welfare state in the shape of quasimarkets: 'if it is believed that workers are primarily knaves and that consumers ought to be king, then the most obvious mechanism of service delivery is the market' (Le Grand, 2006, p. 9; see also Clarke, 2005).

Reshaping clients as users also pays respect to another critique of discretion that is not about implementation but about the protection of citizens' rights in encountering the bureaucracy. Du Gay's 'praise of bureaucracy' stands in contrast to the sometimes dismal view on bureaucrats' use of discretion that can be found in the social policy literature. Goodin (1986), for example, argues that discretionary powers means that officials are in a position to control, manipulate and exploit clients who need the resources over which the official has command. Outcomes may be arbitrary. They appear unpredictable. The need for in-depth information on each case leads to infringements of privacy and 'snooping'. Kumlin and Rothstein found empirical evidence that selective, needs-tested (and thus with a wide scope for SLBs employing discretionary powers) welfare-state institutions reduce interpersonal trust (2005). A logical conclusion seems to be that discretion must be eliminated and curtailed as much as possible. ${ }^{1}$

The NAV reform is neither a pure NPM reform nor an attempt at eliminating discretion. It is a contemporary governance reform that incorporates elements of hierarchical bureaucracy; market mechanisms and NPM-style performance management; and network governance incorporating state, municipal and non-state actors (Andreassen \& Fossestøl, 2014). But NAV's organization and its work procedures are designed with the purpose of providing a framework for the appropriate use of discretion. It is also a very complex organization. NAV is set to implement complex policies, with layers of old and new elements, lofty ideals and practical constraints, which in sum makes up a set of inherent tensions that SLBs need to handle. It is to this handling I now turn.

1 Goodin, in fact, realizes that discretion to a large extent is unavoidable. He suggests rather a rule of generosity, where SLBs should be primarily concerned with granting assistance to everyone who needs it and not be so worried about the prospect that some assistance may also go to those who strictly do not need it, thus reducing the need for intrusion and so forth. 


\subsection{Discretion in Context}

Both Le Grand and Lipsky acknowledge that how street level bureaucrats behave is not external to policy. Whether you are motivated by knightly ideals of the public good or knavish self-interest is not independent of the kind of policies you are given to manage or of the conditions and structures you are doing it within. In other words, policy structures, at least partly, give shape to motivations. In this sense good implementation (and good policy!) is a matter of good governance - establishing governance structures and procedures that facilitate processes which make people approach their work in the desired manner.

At the same time as the structural determinants of bureaucrats' actions are acknowledged, motivations and interests are important elements in much theorizing about street-level bureaucracies. Le Grand (2006) was concerned with the presence of altruism in public sector work. Other accounts focus on how actors can use the leeway of discretionary structures to promote their own interests and thus set off processes of institutional change that were never intended (Mahoney \& Thelen, 2010). Lipsky's work (1980) in a sense fits with this self-interest framework as he portrays SLBs who try to develop coping strategies to make their working life manageable in a context of unresolved tensions and unlimited demands.

But neither altruism nor self-interest as such says much about the actual contents of SLBs' interests and motivations, and how they reflect, interact or conflict with official policy targets. If SLBs apply rough sorting mechanisms to deal with individual cases, which concepts guide them in the sorting process and from which discourses are they drawn? Le Grand's altruism constitutes a very abstract notion and is hardly something people think about or express when reflecting on their work and why and how they do it. Likewise, self-interest says little about the purposes for which discretionary spaces are exploited and in what direction changes are directed. In the space between altruism and self-interest there must be some more specific ideas about what is good and bad, useful and meaningless, worthwhile and futile.

Professional values may be one source of normative ideas about good practice. But many SLBs are not professionals, or they belong to weak professions. In the context of NAV and activation work there is certainly no such established foundation of professional knowledge (Berkel, Aa, \& Gestel, 2010). In any case, professional knowledge can also be ambivalent and patchy, and, as with policy rules, individual discretion must still be applied to infer from general knowledge to practice in individual cases. I want to look further into the ideas and discourses street-level bureaucrats in NAV draw upon when dealing with the tensions and demands of their work. How do NAV staff speak about and argue for their own practices?

As background, it is thus relevant to outline the ideational landscape of social policy practice in Norway.

The Norwegian population of social security dependants is characterized by a high proportion receiving social security for health-related reasons (Barth, Moene, \& 
Pedersen, 2015). People with reduced work capacity accordingly constitute a key target group for work-line policy. A preferred strategy is strengthened activation policies, by which I mean policies that connect rights to income support with participation in active measures (treatment, training, placements etc.) with the aim of enhancing labour market integration. The data I present in this chapter relates to the introduction of a new benefit programme - the work clarification benefit (arbeidsavklaringspenger, $A A P)$ - which imposed stricter activity requirements on the long-term sick. This reflects a general trend where activity conditions are also introduced in health-related benefits, a trend which is underpinned by a discourse in which work and activity are presented as beneficial for a range of health conditions, especially for the milder psychiatric and musculoskeletal diagnoses, which are prevalent in the population receiving health-related benefits (Hagelund, 2014).

AAP was introduced in 2010, shortly after the NAV reform was rolled out in 2006. By merging formerly distinct welfare agencies the idea was that people with complex needs for assistance could find the help they needed behind 'one door' instead of seeking income support in one organization, rehabilitation assistance in another and job-seeking guidance in a third. 'One-stop shops' were thus set up in all municipalities, replacing the more dispersed services that had been offered previously.

Crucial to this chapter, the reform was also to promote work orientation throughout the entire frontline organization rather than compartmentalizing it to certain departments. In other words, the reform aimed to stimulate certain ways of thinking and prioritizing among its frontline workers. By merging many welfare state functions into one locality, the idea was that work targets should permeate all efforts instead of being the responsibility of only dedicated labour market services. Furthermore, the responsibility for assessing (certain, not all) claims for social security, such as disability benefits, was transferred to separate regional 'back offices' without direct client contact. Front-office staff should concentrate on meeting clients, assessing their work ability and supervising them on their trajectory into the labour market. This organizational reform was further accompanied by the reforms of several benefit schemes, typically strengthening the element of compulsory activity requirements, as in the aforementioned AAP scheme.

Also new work procedures were introduced to further strengthen the focus on activity and work targets. Such procedures can be considered means to autopilot reforms (Sørensen, 2005); policy-makers cannot control the day-to-day activities of frontline workers but can put in place institutional procedures ensuring that certain steps are taken and particular considerations met. In this way, the space for discretion is being limited. This included structured methods such as work ability assessments (Gjersøe, 2016) and the development of individual action plans (Born \& Jensen, 2010; Hagelund, 2016). Work ability assessment is a method for assessing individuals' ability to function in the labour market, taking into consideration both social and health factors, and must be done at the entry point to many income security schemes. Following entry, individual action plans are drawn up for each 
individual user's activation, stating the targets of activation and the means (courses, treatments, placements) the user is required to go through to (hopefully) reach the targets (re-entry into the labour market). These are compulsory procedures frontline workers are required to go through with each user, with the purpose of keeping both the officials' and the users' attention on work- and activity-related targets.

Some researchers have talked about a new role for welfare workers following the NAV reform (Helgøy, Kildal, \& Nilssen, 2013). Their work roles are not so much portrayed in terms of being bureaucrats, hierarchically organized neutral officers implementing rules. Rather, they are supervisors, advisors, coaches - applying their relational expertise in helping users realizing their own potentials through workfocused activities. At the same time, they are still in practice bureaucrats bound by the legal frameworks they work within. They do have discretionary powers and are to provide guidance and construe action plans to fit the needs and aims of individuals, but they must also uphold principles of equal treatment and ensure that people's entitlements to income support are upheld. In this sense a new role is layered (Mahoney \& Thelen, 2010) upon the old rather than fully displacing it.

The postwar welfare state has been heavily criticized for its tendencies towards paternalism and for ignoring its users' heterogeneous needs and capacity for autonomous decision-making. Many reforms of the welfare state have thus entailed targets such as a greater degree of tailoring and individualization of services, stronger elements of user choice in the delivery and design of services and the involvement of users in the governance of services and general ideas about user orientated services. This could also be seen as an effort to democratize the welfare state by giving its users a more direct influence on service delivery. An important target for the NAV reform was to place 'the user in the centre' (Hansen, Lundeberg, \& Syltevik, 2013). User orientation is defined as 'to a greater degree letting the needs of the individual user and user groups determine what services should be provided and how they should be provided' (NOU 2004:13, p. 133). NAVs' services should be adapted to the users' often complex needs. The users should have a voice within the process where activation plans are made, targets set and active measures and obligations specified and defined. It does not, however, entail giving up professional authority: 'The users' competence in regard to their own situation must then be compared to the bureaucracy's insights, for example, with respect to demands and opportunities in the labour market' (NOU 2004:13, p. 133) There is a potential tension between the elevation of the user and the user's perspectives on services and the strong normative focus on work and activity as the targets of all NAV's efforts.

In short, the NAV reform has been part of a wider trend of welfare state transformations that entail stronger emphasis on work- and activity-oriented measures and a stronger element of conditionality in the benefit system where rights to income support depend on participation in active measures. The reform also reflects tendencies of individualization, where welfare services should be tailored to meet the needs of individuals and where users' autonomy and competence take a more 
prominent position. This also entails new work roles, where not only return-to-work targets gain a stronger presence in day-to-day practice but also relational competence and the capacity to generate change in clients' lives.

All of this does not mean that NAV work is completely transformed compared to earlier practices. Ideas about activity and health have become more important, but they have not eliminated claims for rest. NAV officials may have embraced a new role as supervisor, but they are still dealing with clients that hold claims pursuant to the National Insurance Act. Recent research indicates, for example, that while responsibilities for work and activation and income support claims have been institutionally divided, frontline staff still take claimants' need for a stable income into consideration when performing work ability assessments (Gjersøe, 2016). Ideas about user orientation are carefully formulated in ways that do not provide the user with the right to veto activity requirements. Precisely because there are continuities, there are also tensions and ambiguities when new rules, procedures and ideals are layered (Mahoney \& Thelen, 2010) on top of old ones. And it is within these tensions and layers SLBs must find a way of operationalizing potentially contradictory targets and ideals in practice. It is to this I now turn.

\subsection{The Work Line and User Orientation in Practice}

The data used in this section are made up of interviews conducted in collaboration with Heidi Moen Gjersøe in two different NAV offices. Our work was curiosity-driven: we simply wanted to learn more about how activation policy is implemented in practice.

One of the questions I initially wanted to illuminate in my part of the project was how an activation and work-driven policy would be implemented in encounters with clients who did not share these aims. I wondered how clients' potential lack of work motivation would be handled in a context where both work orientation and user orientation were held up as key values.

Data were collected at two local NAV offices from October 2012 to February 2013. In total we conducted 25 interviews with street-level bureaucrats (including two local managers), most of whom worked with AAP (work clarification benefits for the longterm sick). The interviews focused in particular on how the SLBs worked with work ability assessments and individual activity plans, both key work procedures within activation policies. By using these very specific work methods as starting points the informants were able to speak concretely about their work and how they solved everyday tasks. In the interviews we also asked questions about conflicts, and the findings presented here are about how the informants talked about the content of disagreements and how they handled such conflicts and tensions. All interviews were taped, transcribed and coded in Nvivo. During the fieldwork we also attended several office and client meetings and collected written material. These data are not directly analyzed here but form a backdrop for the analysis of interview data presented below. 
It is initially worth noting what the NAV informants did not talk about. The stories that emerged about disagreements were rarely about not wanting to work. Rather, disagreements tended to be about what types of work would be relevant for the user and ways of reaching these work targets. There are conflicts with claimants who desire funding for a formal education which NAV is not willing to fund. There are tensions over what types of work that should be targeted, what is realistic and what levels of status drops that claimants must be willing to accept. Indeed one may wonder whether the apparent lack of conflict over the general work orientation of the programmes reflects NAV officers being unwilling to share such kinds of stories about clients or that clients - for pragmatic or genuine reasons - rarely present themselves in such clear opposition to the work goals of NAV. In any case it says something about the presence of a strong work ethic; lacking the drive to work is not a favourable way to present either oneself or others. ${ }^{2}$

What the NAV supervisors did talk about was motivation. Their job, as they portray it, is to detect motivation and, if necessary, to help create motivation. It is difficult to reject a user's idea of a good activity plan if the user is very motivated. If the user has a plan, a dream, rejecting it appears as a violation of the user's own voice.

Well, but in a conversation with a user where to say that 'okay because of an assessment we cannot grant education support', that is very difficult to say because a user is, as said, very motivated to do that [take further education]. (Interview at NAV office)

There is a practical and instrumental element to this story about cherishing motivation; motivated clients are easier to work with. But in general, informants tend to talk about motivating people in normative terms - a value that they strive to achieve in their daily work with clients.

This thing about motivation, and not to force people, is very important. It is important to find something to work towards. But of course, if we had been strict there would be many going into working in shops for example. But we try to find something that can give them a little more motivation. (Interview at NAV office)

To receive AAP the claimant's work ability must be reduced to an extent that prevents her from keeping or gaining paid work. In principle, this could be any kind of work, meaning that if you are unable to do your professor job you must be willing to retrain

2 Survey research does in fact indicate that NAV workers overwhelmingly support the general principles of the work line (Terum, Tufte, \& Jessen, 2012). There have been some concerns that the most developed professional group within NAV, namely social workers, would counteract the work line, as the professional ethic of social workers is not consistent with the work orientation of contemporary welfare policy (Messel, 2013). But the referred research observes only very weak signs of such a distinction between social workers and other staff in NAV (Terum et al., 2012). 
for retail work. In the quote above the informant explains why it can be legitimate to ignore or sidestep this rule: people should be motivated to pursue their activation plans. In the next quote, another informant recounts a similar example and links it explicitly to her own need to apply discretion.

\begin{abstract}
Discretion is perhaps most relevant when it comes to being able to take any type of work. I remember last week I had a case with a woman who is a trained nursing assistant and who had been sick listed. She had no other experience from Norway than care homes and had taken her education here. The physician's report assumed that she would be better within half a year's time. It was mainly physical ailments with respect to walking and standing. The legs were the problem. And I thought when I got home that she could have found work in a shop. And sat all day. Would that have worked? When I did the assessment I thought that as the doctor had written that she probably would be able to return to work as a nursing assistant, and she wanted that herself, and went for treatment at a physiotherapist and there were improvements in sight. There I thought that it is the user's preference to go back to that job. She is trained for it, and it is what she has worked in since she came to Norway. She could have received rejection on the grounds that she is able to sit at the till somewhere, for example. But that was not what happened. (Interview at NAV office)
\end{abstract}

While motivation and the user's own expressed wishes have significant normative force in the stories NAV bureaucrats tell about their work, there are also limits to how far they will stretch their discretionary space to adapt work targets to users' desires. This limit hinges on the perceived realism of their goals and plans. Dreams must be achievable, and motivations must be directed in directions that enable employability.

They are tired of working life and they do yoga, and then they want to be yoga instructors. But there are no jobs in yoga, and then I inform them about that. So we do think about employment opportunities. We want them to come back to work. But we shall not take away from people the desire to move on. (Interview at NAV office)

Because on the one hand they have motivation, wants and desires, but it is not related to (the realities of) the labour market, they will not get a job. It is at least not the simplest way into work. It is much easier to find another work place where they can use the education they already have. And that they are perhaps not motivated for because they have bad experiences with high work pressure and so on. Then you are in a conflict with the user about their dream goals, something they perhaps have always wanted to become. But this is no dream factory. And that is a little difficult to communicate. (Interview at NAV office)

The NAV bureaucrats are on one hand obliged to enforce the strong work aims of the policies they are set to implement. They aim for realistic activation plans with targets that are reachable. In this sense, they place labour market needs and employment targets in the centre. On the other hand, they are also obliged to ideals about user orientation with the user 'in the centre'. The value of acknowledging and respecting the aims and preferences expressed by users is related to motivation; if users are motivated to reach their aims, chances are they will work harder to achieve them. As long as the desires of the users appear coherent with the realities of the labour 
market, the informants are willing to use their discretionary space to accommodate users' claims.

But how do they handle the aims that are referred to as dreams and assessed to be unrealistic? - by working on them, modifying them and transforming them into something more achievable.

- Do you sometimes think that the user has goals which are unrealistic? - Yes, sometimes that happens. - How do you solve that? - Try to supervise a little. But I am a little concerned about not taking dreams away from people. Say that a user for example wants to become a lawyer. Perhaps this person can become a lawyer's secretary? Not ruin the dreams, but we need to be realistic. Not float on a cloud. And I am very clear on not educating for unemployment, to not grant too narrow an educational field. (Interview at NAV office)

But we do try to make him look at other opportunities. He has skills in other directions. Try to make him think about finding other legs to stand on. If I should just say that this is not going to happen, forget it, I think it would be much more difficult for him to motivate himself for other alternatives. (Interview at NAV office)

In implementing policy NAV bureaucrats must deal with the tension between the political call for the work line and the voice of the user as expert on him/herself. But while a user may be conceived as knowledgeable about himself, this does not make him an expert on the realities of the labour market. This becomes the task of the NAV supervisors: to assess the realism of the users' preferences and to mould perceived unrealism into something judged to be attainable.

However, judging what is possible or not in the labour market for people who often suffer from complex and diffuse health problems is not a straightforward task, and there are few, if any, established procedures to distinguish the attainable from the improbable. One potential consequence is that this in practice weakens the work orientation. Gjersøe (2016) has shown that NAV supervisors often end up relying on the clients' own accounts of what is possible or not when considering whether someone can return to his/her own area of work. Likewise, as it is hard to judge whether it really will be possible to find employment in a new area despite health problems, further work to 'strengthen motivation' or further improve skills may be considered less risky for users than to discontinue the allowance and transfer AAP users into job-seeker status. On the other hand, in the situations where users' own initiatives to obtain retraining for a new career in another field are turned down, they are likely to experience NAV as rigid and unforthcoming.

\subsection{Democracy at the Street-Level?}

In the introduction, the editors ask if it is possible for a strong state to be truly liberal (Engelstad, Holst, \& Aakvaag, this volume). Current trends in welfare state 
development point towards stronger elements of conditionality and pressures to ensure that social security recipients engage in activities designed to facilitate their return to work. Passive income compensation schemes are transformed into activation tools (Bonoli \& Natali, 2012). In this sense the state seems to become stronger and less liberal, with the welfare institutions taking a more active role in producing a particular type of citizen, namely an active citizen who is able to support him/herself through gainful employment. But there are nuances to this picture. This kind of social investment into citizens with health problems could also be seen as efforts to enhance their autonomy, transforming them from passive recipients via active users to, in the end (if the policies work according to plan), self-sufficient workers. Furthermore, strict activation requirements are complemented with imperatives of user orientation and user involvement, supposed to give users a voice in determining their own activation programmes.

Welfare reforms, in a country like Norway, constitute complex compromises. New institutional structures are erected, but not all old ones are eradicated. Instead processes of institutional layering occur, where new rules and ideals are introduced alongside old ones. In this way substantial change can occur incrementally, as the addition of one layer affects the logic or modus operandi of another one (Mahoney \& Thelen, 2010). At one level, NAV has displaced earlier institutions. National labour market services and social security services no longer exist. But the organizational reform did not displace existing income security structures or citizen entitlements embedded in the National Insurance Act. New activation policies are layered upon existing social security institutions - user orientation and new supervisor roles on top of bureaucratic hierarchical relations. These tensions and ambivalences mean that discretionary spaces widen and that street-level bureaucrats are tasked with making practical solutions in situations with complex and contradictory claims.

SLBs are thus vital to the implementation of democratically conceived policy. Without efficient implementation, citizens will not receive the services and benefits they are entitled to, and policies will remain paper tigers and symbolic statements. They command a considerable space of discretionary judgement, which they can use to interpret rules and design and deliver services in unintended ways. Through direct encounters with citizens, they quite literally make up the human faces of the welfare state with potentially significant impacts on citizens' trust in the state and in democratic institutions. Contemporary welfare reforms also give them a role in determining the ability of welfare programmes to form part of a democratic society (Engelstad, Holst, \& Aakvaag, this volume), where welfare users are not pushed around but are instead enabled to take control of their own lives.

As reforms are complex with internal tensions and multiple layers, the implementation of democratic decisions can take different paths depending on the adaptations that are made in local street-level bureaucracies. In this chapter I looked in particular at the potential ambivalences emanating from the simultaneous 
implementation of work line principles and user orientation. One can envision several ways of managing these in practice, each with potential pitfalls.

Activation policies can be implemented with a stern eye on activity requirements. The bureaucratic apparatus may become so focused on activity requirements that it fails to recognize the reduced capacities of social security users to take part in them or to actually benefit from them. The ticking off of activity boxes is measurable and within the power of SLBs to achieve. Whether this actually entails increased labour market participation as a result of the activation measures is both harder to observe and harder to control as SLBs have few ways of influencing employer preferences. NPM style performance measurements may enhance such tendencies. When departments and/or workers are monitored and measured on their ability to refer users to active measures, the referral itself may become the main goal. Strict bureaucratic rules may perform a similar function, such as when activity becomes a requirement for the payment of benefits irrespective of the actual ability of participants to profit from the use of such measures.

Organizational needs and constraints may also overshadow the substantive targets of policy. A bureaucracy that is or feels overstretched on resources may turn its main focus towards finding ways of adapting policy goals that make workloads bearable. These are the type of coping mechanisms Lipsky outlined, such as finding rules of thumb to process complex cases by way of simple characteristics. An example would be if all plans for future labour market reintegration by means of entering the yoga business were dismissed as unrealistic without considering the actual competencies of the user and the local market for yoga classes. (After all, for a former athlete residing in an affluent area, yoga instruction could possibly be a viable way of making a living.) NAV supervisors are supposed to know enough about the labour market to assess people's opportunities to find work given the competencies they have or can achieve through active measures. This is obviously quite difficult to predict as there is no codified knowledge base to draw on (Berkel et al., 2010), and simple rules of thumb characterizing certain career paths as unrealistic or using certain individual traits (age, language skills, diagnoses) to disqualify users from particular tracks may easily evolve.

Working on motivation, in my analysis, was the crucial idea that SLBs applied to reconcile divergent claims into the formulation of individual action plans and thus into the delivery of work line policy. This is an idea that gives higher priority to user orientation principles by seeking to align users' wishes and claims with the activation policies NAV is set to implement. The informants in this study were reluctant to narrate conflicts and instead told stories about working with clients to produce inner transformations that aligned individual preferences with official requirements. This is a strategy that also reflects a trend in contemporary welfare state reforms that reconstitutes the role of SLBs from being case managers to becoming supervisors (Born \& Jensen, 2010). This kind of work is not about approving or denying applications according to rules set by politicians (the Weberian bureaucrat) but about 
assisting users in formulating and reaching their own goals. This not only widens the discretionary space of frontline workers but also introduces another kind of authority into their work, namely the voice of the user.

In one sense, the frontline activation workers seem to have lost some of their former authority as gatekeepers proficient in assessing eligibility for social security. However, they have carved out a new role in assessing the realism of users' dreams and plans for finding a way out of social security. One study (Gjersøe, 2016) suggests that the insecurities attached to SLBs' assessments of users' actual labour market potentials make them susceptible to give priority to the users' own and their physicians' assessments of work ability. In this sense, it is the users' knowledge of themselves and ability to present this convincingly which may make them 'queens' in activation policy, to reiterate Le Grand's terminology. On the other hand, these are policies which simultaneously have weakened their entitlements to social security by conditioning it upon adherence to the activation requirements of NAV officials.

\section{References}

Andreassen, T. A., \& Fossestøl, K. (2011). Innledning - organisasjonsendring som velferdsreform. In T. A. Andreassen \& K. Fossestøl (Eds.) NAV ved et veiskille. Organisasjonsendring som velferdsreform. Oslo: Gyldendal Akademisk.

Andreassen, T. A., \& Fossestøl, K. (2011). Utfordrende inkluderingspolitikk. Samstyring for omforming av institusjonell logikk i arbeidslivet, helsetjenesten og NAV. Tidsskrift for samfunnsforskning, 55(2), 174-202.

Bay, A.-H. (2015). Myndighet krever kompetanse. Op-ed in Dagens Næringsliv 17.05.2015. Retrieved from http://www.dn.no/meninger/debatt/2015/05/17/2101/Nav/myndighet- kreverkompetanse [Accessed 27.06.2016].

Berkel, R. v., Aa, P. v. d., \& Gestel, N. v. (2010). Professionals without a Profession? Redesigning Case Management in Dutch Local Welfare Agencies. European Journal of Social Work, 13(4), 447-463.

Berkel, R. v., \& Aa, P. v. d. (2012). Activation Work: Policy Programme Administration or Professional Service Provision? Journal of Social Policy, 41(3), 493-510.

Bonoli, G. \& Bonoli, G. \& D. Natali (2012). The Politics of the 'New' Welfare States: Analysing Reforms in Western Europe. In G. Bonoli \& D. Natali The Politics of the New Welfare State. Oxford: Oxford University Press.

Born, A. W., \& Jensen, P. H. (2010). Dialogue-based activation - a new 'dispositif'? International Journal of Sociology and Social Policy, 30(5/6), 326-336.

Brodkin, E. Z. (2013). Street-Level Organizations and the Welfare State. In E. Z. Brodkin \& G. Marston (Eds.) Work and the Welfare State. Street-Level Organizations and Workfare Politics. Copenhagen: Djøf Publishing.

Clarke, J. (2005). New Labour's Citizens: Activated, Empowered, Responsibilized, Abandoned? Critical Social Policy, 25(4), 447-463.

Du Gay, P. (2000). In praise of bureaucracy. London: SAGE.

Ekspertgruppen (2015). Et NAV med muligheter. Bedre brukermøter, større handlingsrom og tettere på arbeidsmarkedet. Oslo: Ekspertgruppen. https://www.regjeringen.no/globalassets/ departementene/asd/dokumenter/2015/sluttrappo rt-ekspertgruppen-nav_9.4.15.pdf 
Esping-Andersen, G. (1990). The Three Worlds of Welfare Capitalism. Cambridge: Polity Press. Gjersøe, H. M. (2016). Getting Sick and Disabled People off Temporary Benefit Receipt: Strategies and Dilemmas in the Welfare State's Frontline. Nordic Journal of Working Life Studies, 6, 129-145.

Goodin, R. E. (1986). Welfare, Rights and Discretion. Oxford Journal of Legal Studies, 6(2), 232-261.

Hagelund, A. (2016). The Activating Profession. Coaching and Coercing in the Welfare Services. International Journal of Public Sector Management, 29(7), 725-739.

Hansen, H.-T., Lundberg, K., \& Syltevik, L. J. (2013). Nav - med brukeren i sentrum. En introduksjon. In H.-T. Hansen, K. Lundberg \& L. J. Syltevik (Eds.), Nav - med brukeren i sentrum? Oslo: Universitetsforlaget.

Helgøy, I., Kildal, N., \& Nilssen, E. (2013). Utvikling av en arbeidsrettet spesialistrolle i Nav. Tidsskrift for velferdsforskning, 16(3), 141-156.

Kumlin, S., \& Rothstein, B. (2005). Making and Breaking Social Capital. The Impact of Welfare-State Institutions. Comparative Political Studies, 38(4), 339-365.

Le Grand, J. (2003). Motivation, Agency and Public Policy. Of Knights \& Knaves, Pawns \& Queens. Oxford: Oxford University Press.

Lipsky, M. (1980). Street-level bureaucracy. Dilemmas of the individual in public services. New York: Russel Sage Foundation.

Messel, J. (2013). I velferdsstatens frontlinje. Barnevernspedagogers, sosionomers og vernepleieres historie. Oslo: Universitetsforlaget.

Molander, A. (2016). Discretion in the Welfare State. London: Routledge.

NOU (2004:13). En ny arbeids- og velferdsforvaltning. Om samordning av Aetats, trygdeetatens og sosialtjenestens oppgaver. Oslo: Statens forvaltningstjeneste.

Newman, J. (2007). The 'Double Dynamics' of Activation. International Journal of Sociology and Social Policy, 27(9/10), 364-375.

Pierson, P. (2006). Public Policies as Institutions. In I. Shapiro, S. Skowronek \& D. Galvin (Eds.) Rethinking Political Institutions. The Art of the State. New York: New York University Press.

Rothstein, B. (1998). Just Institutions Matter: The Moral and Political Logic of the Universal Welfare State. Cambridge: Cambridge University Press.

Syltevik, L. J. (2013). 'Brukeren' i debatten om Nav-reformen. In H.-T. Hansen, K. G. Lundberg \& L. J. Syltevik (Eds.) Nav - med brukeren i sentrum? Oslo: Universitetsforlaget.

Sørensen, R. (2005). Et folkestyre i fremgang. Demokratisk kontroll med brannalarmer og autopiloter. Nytt Norsk Tidsskrift, 3, 258-270.

Terum, L. I., Tufte, P. A., \& Jessen, J. T. (2012). Arbeidslinja og sosialarbeiderne. In S. Stjernø \& E. $\emptyset$ verbye (Eds.) Arbeidslinja. Oslo: Universitetsforlaget. 